\title{
Gene expression dysregulated of Long Chain Non- coding RNA in patients with idiopathic achalasia: New Insight into Pathogenesis
}

\section{Chao Lu}

The First Affiliated Hospital, Zhejiang University School of Medicine Hongtao Zhang

The First Affiliated Hospital, Zhejiang University School of Medicine

Furong Wei

The First Affiliated Hospital, Zhejiang University School of Medicine

\section{Xin Yao}

The First Affiliated Hospital, Zhejiang University School of Medicine

Chaohui Yu ( $\nabla$ zyyyych@zju.edu.cn )

Zhejiang University School of Medicine First Affiliated Hospital

\section{Research}

Keywords:

Posted Date: September 16th, 2020

DOI: https://doi.org/10.21203/rs.3.rs-41940/v2

License: (c) (i) This work is licensed under a Creative Commons Attribution 4.0 International License. Read Full License 


\section{Abstract}

The authors have requested that this preprint be withdrawn due to erroneous posting.

\section{Full Text}

The authors have withdrawn this preprint from Research Square. 